Jerzy Bieluk ${ }^{1}$

\title{
Zasady zwolnienia gospodarstw rolnych z podatku od spadków i darowizn
}

\section{Zagadnienia wstępne}

Przedmiotem niniejszego artykułu jest obecna regulacja dotycząca opodatkowania dziedziczenia i darowizny gospodarstw rolnych ${ }^{2}$. Ustawą $\mathrm{z}$ dnia 16 listopada 2006 r. o zmianie ustawy o podatku od spadków i darowizn oraz ustawy o podatku od czynności cywilnoprawnych ${ }^{3}$ obowiązującą od 1 stycznia 2007 r. dokonano znacznych zmian w systemie opodatkowania przysporzeń pod tytułem darmym. Najważniejszą z punktu widzenia podatników zmianą jest zwolnienie osób bliskich spadkobiercy i darczyńcy od podatku z tytułu nabycia własności rzeczy lub praw majątkowych. Od 1 stycznia 2007 r. od podatku od spadków i darowizn zwolnione są przysporzenia na rzecz małżonka, zstępnych, wstępnych, pasierbów, rodzeństwa, ojczyma i macochy. Ustawodawca wybrał występujący zresztą dosyć powszechnie na świecie system zwolnienia dziedziczenia i darowizn w kręgu najbliższej rodziny $\mathrm{z}$ opodatkowania.

Spadkobranie i darowizny dotyczące osób spoza określonego powyżej kręgu nie korzystają ze zwolnienia. W przypadku dziedziczenia wykroczenie poza krąg osób zwolnionych ma miejsce $\mathrm{z}$ reguły w przypadku istnienia testamentu, jednak również na podstawie ustawy dziedziczyć mogą osoby niezwolnione z podatku. Nie wchodzą w sferę podmiotów zwolnionych na przykład zstępni rodzeństwa - a mogą dziedziczyć ustawowo (art. 932 kc.). Szczególnie przy rozszerzeniu zakresu podmiotów dziedziczących nowelą Kodeksu cywilnego z dnia 18 marca 2011 r. krąg podmiotów dziedziczących ustawowo, a nieobjętych zwolnieniem, uległ znacznemu powiększeniu ${ }^{4}$.

\footnotetext{
Uniwersytet w Białymstoku.

Omówienie poprzedniej regulacji por. J. Bieluk, Podatek od spadków i darowizn w rolnictwie, „Rejent” 2000, nr 11, s. 13-26.

Dz.U. Nr 222, poz. 1629

Na mocy ustawy z dnia 18 marca 2011 r. o zmianie ustawy - Kodeks cywilny oraz niektórych innych ustaw (Dz. U. Nr 85, poz. 458) do podmiotów nieobjętych zwolnieniem, a mogących dziedziczyć z ustawy, doszli zstępni dziadków spadkodawcy.
} 
Zwolnienie nie dotyczy też osób będących w bliskich stosunkach z daną osobą - na przykład konkubentów, którzy nie zalegalizowali swojego związku. W praktyce rozporządzenia testamentowe na rzecz tej kategorii osób zdarzają się często. W związku z powyższym, mimo iż większość darowizn i większość spadków dotyczy najbliższej rodziny, znajdującej się w kręgu osób zwolnionych z opodatkowania podatkiem od spadków i darowizn, nadal zakres zwolnień określonych ustawą ma ogromne znaczenie praktyczne w pozostałych, nieobjętych zwolnieniami podmiotowymi sytuacjach. Ustawa o podatku od spadków i darowizn zawierała i wciąż zawiera katalog zwolnień przedmiotowych. Jednak straciły one znacznie na swojej ważności z uwagi na wspomniane wyżej zwolnienia podmiotowe. Z pewnością rzadziej korzysta się z nich w praktyce niż dotychczas. $Z$ drugiej strony darowizny oraz przeznaczenie w testamencie majątku na rzecz osób spoza najbliższej rodziny nie jest rzadkością i z pewnością należy ściśle oraz w sposób niepozostawiający wątpliwości co do zakresu stosowania przepisów określić, co i pod jakimi warunkami będzie zwolnione $\mathrm{z}$ opodatkowania.

Ustawą z dnia 16 listopada 2006 r. o zmianie ustawy o podatku od spadków i darowizn zmieniono regulację dotyczącą zwolnienia przekazania pod tytułem darmym gospodarstwa rolnego. Poprzednio zwolnienie obejmowało:

1) nabycie własności i prawa użytkowania wieczystego gospodarstwa rolnego lub jego części oraz innych praw do takiego gospodarstwa lub jego części, jak również działki przyzagrodowej, z wyjątkiem:

a) budynków mieszkalnych,

b) budynków zajętych na cele specjalistycznego chowu i wylęgu drobiu lub specjalistycznej hodowli zwierząt wraz z urządzeniami i ze stadem hodowlanym,

c) urządzeń do prowadzenia upraw specjalnych, jak: szklarnie, inspekty, pieczarkarnie, chłodnie, przechowalnie owoców5 5 .

Regulacja ta budziła szereg kontrowersji, jeżeli chodzi o zakres zwolnienia ${ }^{6}$. Nie do rozstrzygnięcia na drodze literalnej interpretacji ustawy był problem, czy zwolnienie gospodarstwa rolnego obejmowało również budynki i budowle inne niż wymienione jako opodatkowane pod lit. a), b) i c) omawianego przepisu. Również stanowisko Ministerstwa Finansów ${ }^{7}$ było w tym zakresie niejednolite. Niekiedy wykluczano zwolnienie budynków i budowli ze zwolnienia, niekiedy przyjmowano, iż takie zwolnienie jest zgodne z intencją ustawodawcy, choć nie znajduje bezpośredniego potwierdzenia $\mathrm{w}$ treści ustawy ${ }^{8}$.

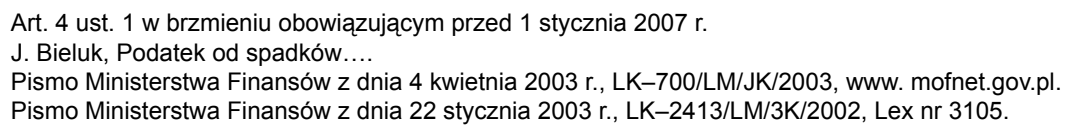


Nowelizacja z dnia 16 listopada 2006 r. zmieniła powyższą regulację. Inaczej określono zakres zwolnienia, co ma duże konsekwencje praktyczne. Zmieniono treść art. 4 i obecnie zwolnienie określone jest następująco.

Zwalnia się od podatku:

1) nabycie własności lub prawa użytkowania wieczystego nieruchomości lub jej części wraz z częściami składowymi, z wyjątkiem:

a) budynków mieszkalnych,

b) budynków zajętych na cele specjalistycznego chowu i wylęgu drobiu lub specjalistycznej hodowli zwierząt wraz z urządzeniami i ze stadem hodowlanym,

c) urządzeń do prowadzenia upraw specjalnych, jak: szklarnie, inspekty, pieczarkarnie, chłodnie, przechowalnie owoców - pod warunkiem, że w rozumieniu przepisów o podatku rolnym, w chwili nabycia, ta nieruchomość stanowi gospodarstwo rolne lub jego część albo wejdzie w skład gospodarstwa rolnego będącego własnością nabywcy i to gospodarstwo rolne będzie prowadzone przez nabywcę przez okres co najmniej 5 lat od dnia nabycia.

Najważniejszą zmianą wprowadzoną przez ustawodawcę jest przesunięcie zakresu zwolnienia z gospodarstwa rolnego na nieruchomość - i w drugim etapie uzależnienie zwolnienia od tego, czy ta nieruchomość wchodzi w skład gospodarstwa rolnego w rozumieniu przepisów ustawy o podatku rolnym. Należy określić, jakie ta zmiana ma konsekwencje.

Zwolnione jest nieodpłatne nabycie nieruchomości; zaś wobec braku możliwości odwołania się do innych przepisów i braku jakichkolwiek wskazań co do innego sposobu rozumienia tego pojęcia, winniśmy rozumieć pojęcie nieruchomości w znaczeniu prawnorzeczowym, odwołując się do definicji z kodeksu cywilnego. Zgodnie $\mathrm{z}$ art. $46 \mathrm{kc}$. nieruchomości to części powierzchni ziemi stanowiące odrębny przedmiot własności (grunty), jak również budynki trwale z gruntem związane lub części takich budynków, jeżeli na mocy przepisów szczególnych stanowią odrębny od gruntu przedmiot własności. Jednak nieruchomości budynkowe i lokalowe nie będą wchodziły w zakres zwolnienia. Odwołanie do definicji podatkowej gospodarstwa rolnego, według której jedynym składnikiem gospodarstwa są grunty, powoduje iż, zwolnienie może dotyczyć wyłącznie nieruchomości gruntowych.

\section{Zakres przedmiotowy zwolnienia}

Zgodnie z artykułem 4 ustawy o podatku od spadków i darowizn zwolnienie obejmuje nabycie własności lub prawa wieczystego użytkowania nieruchomości. To sformułowanie jest jasne i precyzyjne. Natomiast dalej ustawodawca dodaje „lub jej 
części” i tu zaczyna się problem. Zwolnienie nabycia części nieruchomości może budzić poważne wątpliwości na gruncie prawa cywilnego. Posługując się wieczystoksięgowym pojęciem nieruchomości, uznać należy, iż nie można nabyć części nieruchomości. Nieruchomość to część powierzchni ziemi, która może stanowić samodzielny przedmiot obrotu ${ }^{9}$. Innymi słowy, niemożliwy jest obrót częścią nieruchomości. Nie można być właścicielem części nieruchomości ${ }^{10}$. Nie może więc część nieruchomości być przedmiotem nabycia. Założyć zatem należy, iż ustawodawca miał na myśli taką sytuację, gdy - na przykład - wolą spadkodawcy wyrażoną w testamencie był podział należącej do niego nieruchomości i przekazanie części tak wydzielonej jednemu ze spadkobierców. Wtedy, po podziale nieruchomości, okaże się, że część wydzielona stanowi samodzielną nieruchomość i przekazaniu na mocy testamentu ulegnie właśnie nieruchomość powstała po podziale ${ }^{11}$. Sformułowanie to, mimo iż nieprecyzyjne, nie ma jednak większego znaczenia dla rzeczywistego zakresu zwolnienia. Należy przyjąć tylko, iż przy rozporządzeniu testamentowym częścią nieruchomości - co prawnie przy właściwej interpretacji woli spadkodawcy jest możliwe - skutki podatkowe takiego rozporządzenia określamy po ich skutkach prawnorzeczowych. Na przykład przyznanie budynków gospodarczych oddzielnie kilku spadkobiercom może być uważane za:

- skutkujące uznaniem danych osób za współwłaścicieli (ściśle rzecz biorąc, możemy mieć do czynienia ze wspólnością masy spadkowej),

- zapis, który powoduje obowiązek określonego działania - w takim wypadku działania w kierunku podziału nieruchomości zgodnie z wolą spadkodawcy i po podziale przekazania części powierzchni ziemi będącej przedmiotem zapisu już jako oddzielnej nieruchomości zapisobiercy.

Dalej ustawodawca określa zwolnienie w duchu cywilistycznym, stwierdzając, iż zwolnieniu podlega nabycie nieruchomości wraz z częściami składowymi. Części składowe - rozumieć należy zgodnie z art. 47 § 2 kc. - jako wszystko, co nie może być od rzeczy odłączone bez uszkodzenia lub istotnej zmiany całości albo bez uszkodzenia lub istotnej zmiany przedmiotu odłączonego. Jeżeli chodzi o części składowe nieruchomości, mamy dodatkowo sprecyzowany zakres tego pojęcia

S. Rudnicki, Prawo obrotu nieruchomościami, Warszawa 1999, s. 11: część powierzchni ziemskiej jest w znaczeniu użytym w pierwszej części tego zdania (art. 46 kc.) odrębnym przedmiotem własności, jeżeli jest oddzielona w znaczeniu prawnym od pozostałej powierzchni w taki sposób, że może stanowić samodzielny przedmiot obrotu prawnego. Cały czas posługujemy się w tych rozważaniach wieczystoksięgowym pojęciem nieruchomości, gdyż uznać należy, iż takie pojęcie jest najbardziej precyzyjne, jeżeli chodzi o potrzeby obrotu. Oczywiście można być właścicielem udziału w nieruchomości, ale zawsze będzie to udział w całości nieruchomości.

11 Można wyobrazić sobie taki dział spadku, gdy przedmiotem przekazania będzie działka gruntu. Gdy z jednej księgi odłączymy tę działkę i od razu dołączymy do drugiej, wtedy rzeczywiście nie będzie etapu, gdy część nieruchomości - działka gruntu będzie samodzielną nieruchomością, tylko od razu stanie się częścią drugiej nieruchomości. 
$\mathrm{w}$ art. $48 \mathrm{kc} .{ }^{12}$ zgodnie z którym z zastrzeżeniem wyjątków w ustawie przewidzianych do części składowych gruntu należą w szczególności budynki i inne urządzenia trwale z gruntem związane, jak również drzewa i inne rośliny od chwili zasadzenia lub zasiania. Odniesienie do pojęcia części składowych służy do jednoczesnego określenia wyjątków, które nie podlegają zwolnieniu. Zwolnieniu podlegają wszystkie części składowe nieruchomości z wyjątkiem określonych art. 4 pod lit. a), b) i c). Części składowe nieruchomości to: budynki i inne urządzenia trwale z gruntem związane takie jak studnie, silosy, ogrodzenie oraz urządzenia wymienione w art. 49 kc. - do doprowadzania wody, pary, gazu, prądu elektrycznego - jeżeli nie wchodzą w skład przedsiębiorstwa, przedmioty połączone $\mathrm{z}$ budynkami ${ }^{13}$, drzewa $\mathrm{i}$ inne rośliny od chwili zasadzenia lub zasiania, prawa związane z nieruchomością, takie jak służebności gruntowe.

Odróżnić należy pojęcie części składowej nieruchomości od pojęcia przynależności nieruchomości. Zgodnie z art. $51 \S 1 \mathrm{kc}$. przynależnościami są rzeczy ruchome potrzebne do korzystania $z$ innej rzeczy (rzeczy głównej) zgodnie z jej przeznaczeniem, jeżeli pozostają z nią w faktycznym związku odpowiadającym temu celowi. Czynność prawna dotycząca nieruchomości obejmuje w zasadzie również przynależności nieruchomości - art. $52 \mathrm{kc}$. Przynależnościami będą np. budynki $\mathrm{i}$ inne urządzenia w przypadku, gdy nie są trwale związane $\mathrm{z}$ gruntem, natomiast istnieje między nieruchomością a tymi urządzeniami jakaś więź funkcjonalna. Przynależnościami nieruchomości rolnej może być na przykład inwentarz żywy i martwy ${ }^{14}$. Odróżnienie części składowej od przynależności ma zasadnicze znaczenie przy określaniu zakresu zwolnienia. Przynależności, mimo iż z reguły przypadające wraz z nieruchomością obdarowanemu lub spadkobiercy, nie będą objęte zwolnieniem, natomiast części składowe będą zwolnione od podatku od spadków i daro$\operatorname{wizn}^{15}$.

Jedynym składnikiem gospodarstwa rolnego zgodnie z definicją z ustawy o podatku rolnym są grunty. Części składowe nie wchodzą w skład tak rozumianego gospodarstwa rolnego. Jednak wobec stanowczego brzmienia ustawy nie ulega wątpliwości, że części składowe nieruchomości w rozumieniu prawnorzeczowym - czyli budynki, budowle itd. - są objęte zwolnieniem w zakresie podatku od spadków i darowizn. Zakres przedmiotowy zwolnienia jest więc znacznie rozszerzony w stosunku do definicji powoływanej jako podstawa zwolnienia. Jednak zrobiono to w sposób niejako poboczny. Zamiast - co wydawałoby się najbardziej właściwe - odwołać

12 Kontrowersje na temat stosunku art. 48 kc. do art. 47 kc. zob. M. Bednarek, Mienie. Komentarz do art. 44-55(3) Kodeksu cywilnego, Kraków 1997, s. 151.

13 „[...] w zależności od sytuacji prawnej budynku - przedmioty połączone z budynkiem będą stanowiły albo części składowe gruntu (gdy budynek jest częścią składową gruntu), albo części składowe budynku (gdy budynek stanowi odrębną nieruchomość)", tak M. Bednarek, Mienie..., s. 150. Por. M. Bednarek, Mienie..., s. 162. zwolnieniu. 
się do definicji gospodarstwa rolnego z kodeksu cywilnego przy określaniu zakresu zwolnienia, nadal ustawodawca posługuje się niedostosowanym do potrzeb obrotu - w tym darowizn i spadkobrania - pojęciem gospodarstwa rolnego z ustawy o podatku rolnym.

\section{Warunki zwolnienia}

Zwolnienie opisywane powyżej (art. 4 ustawy) ma zastosowanie pod warunkiem, że w rozumieniu przepisów o podatku rolnym w chwili nabycia ta nieruchomość stanowi gospodarstwo rolne lub jego część albo wejdzie w skład gospodarstwa rolnego będącego własnością nabywcy i to gospodarstwo rolne będzie prowadzone przez nabywcę przez okres co najmniej 5 lat od dnia nabycia. Należy szczegółowo przeanalizować zakres znaczeniowy powyższego przepisu, gdyż ma on zasadniczą wagę dla funkcjonowania zwolnienia.

Zwolnienie ma zastosowanie pod warunkiem, że w rozumieniu przepisów o podatku rolnym w chwili nabycia ta nieruchomość stanowi gospodarstwo rolne lub jego część. Pojęcie gospodarstwa rolnego jest więc pojęciem podstawowym dla określenia przedmiotu podatku rolnego.

Zgodnie z ustawą o podatku rolnym ${ }^{16}$ (art. 1 i art. 2 ustawy) za gospodarstwo rolne uważa się obszar gruntów, sklasyfikowanych w ewidencji gruntów i budynków jako użytki rolne lub jako grunty zadrzewione i zakrzewione na użytkach rolnych, z wyjątkiem gruntów zajętych na prowadzenie działalności gospodarczej innej niż działalność rolnicza ${ }^{17}$, o łącznej powierzchni przekraczającej 1 ha lub 1 ha przeliczeniowy, stanowiących własność lub znajdujących się w posiadaniu osoby fizycznej, osoby prawnej albo jednostki organizacyjnej, w tym spółki, nieposiadającej osobowości prawnej ${ }^{18}$. Definicja jest wyraźnie funkcjonalna, jej kształt jest zdeterminowany przez wyznaczony jej przez ustawodawcę cel, ma za zadanie jasno i precyzyjnie określić zasadniczą dla każdego podatku kwestię - podstawę opodatkowania. Jednak odrębną rzeczą jest to, czy definicja stworzona na potrzeby opodatkowania gruntów rolnych równie dobrze nadaje się do określenia zakresu zwolnienia w podatku od spadków i darowizn.

Zakres przedmiotowy definicji obejmuje wyłącznie grunty ${ }^{19}$. Grunty te jednak muszą spełniać określony warunek - muszą stanowić część gospodarstwa rolnego -

16 Ustawa z dnia 15 listopada 1984 r. o podatku rolnym, tekst jedn. Dz.U. z 2006 r. Nr 136, poz. 969, z późn. zm.

17 Por. art. 2 ust. 2 ustawy o podatku dochodowym od osób fizycznych i podobnie art. 2 ust. 2 ustawy o podatku dochodowym od osób prawnych. Por. też art. 3 ust. 2 ustawy z dnia 12 stycznia 1991 r. o podatkach i opłatach lokalnych, tekst jedn. Dz.U. z 2006 r. Nr 121, poz. 844.

18 Na temat ujęcia prawnego i ekonomicznego pojęcia gospodarstwa rolnego por. S. Prutis, Pozycja prawna państwowych przedsiębiorstw gospodarki rolnej, Białystok 1987, s. 36 i n.; R. Budzinowski, Koncepcja gospodarstwa rolnego w prawie rolnym, Poznań 1992, s. 77 i n.

19 Zakres poszczególnych pojęć związanych z definicją gospodarstwa rolnego zdefiniowany jest w rozporządzeniu Ministra Rozwoju Regionalnego i Budownictwa z dnia 29 marca 2001 r. w sprawie ewidencji gruntów i budynków, Dz.U. Nr 38, poz. 454. 
określonego poprzez minimalny próg wielkości powierzchni gruntu - o łącznej powierzchni przekraczającej 1 ha lub o powierzchni użytków rolnych przekraczającej 1 ha przeliczeniowy.

Trzecim elementem definicji, obok określenia rodzaju gruntów oraz ich minimalnej wielkości, jest określenie stosunku danego podmiotu prawnego do gruntu. Dany grunt musi stanowić własność lub znajdować się w posiadaniu osoby fizycznej lub osoby prawnej albo jednostki organizacyjnej, w tym spółki niemającej osobowości prawnej. W przeciwieństwie do definicji z kodeksu cywilnego ${ }^{20}$ definicja z ustawy o podatku rolnym nie zawiera warunku istnienia łączności ekonomicznej między poszczególnymi składnikami gospodarstwa. Decydujące o zaliczeniu danego gruntu do użytków rolnych są dane z ewidencji gruntów. Należy uznać, iż zgodnie $\mathrm{z}$ ustawą o podatku rolnym grunt jest użytkiem rolnym, jeżeli tak został określony w ewidencji gruntów. Decyduje więc nie faktyczne wykorzystywanie gruntów, ale ich klasyfikacja w ewidencji ${ }^{21}$. Podobnie grunt wykorzystywany rolniczo, a niebędący użytkiem rolnym, na przykład grunt zaliczony do zurbanizowanych terenów niezabudowanych, nie będzie wchodził w skład gospodarstwa rolnego, ponieważ dane w ewidencji gruntów na to nie wskazują. Z drugiej strony grunt położony w granicach miasta, przekraczający 1 ha i mający w ewidencji zapis - użytki rolne będzie gospodarstwem rolnym w rozumieniu przepisów ustawy o podatku rolnym, mimo iż nie jest, a nawet nie może być - np. z powodu znacznego zanieczyszczenia powietrza w pobliżu ciągów komunikacyjnych - wykorzystywany rolniczo.

Nieruchomość stanowi gospodarstwo rolne wtedy, gdy spełnia warunki określone powyżej. Zgodnie z ustawą o podatku od spadków i darowizn możemy mieć do czynienia z dwiema sytuacjami. Pierwsza, w której przedmiotem darowizny (spadkobrania) jest gospodarstwo rolne w rozumieniu ustawy o podatku rolnym i druga, gdy przedmiotem darowizny (spadkobrania) jest część gospodarstwa rolnego. Przedmiotem darowizny (spadkobrania) są wtedy grunty rolne o powierzchni przekraczającej 1 ha (1 ha przeliczeniowy). Sytuacja druga wymaga komentarza. Nieruchomość będzie częścią gospodarstwa rolnego wtedy, gdy przed spadkobraniem czy przed zawarciem umowy darowizny będzie wchodziła w skład gospodarstwa rol-

Brak zastosowania definicji z art. $55^{3} \mathrm{kc}$. do celów podatkowych wyraźnie określił NSA w wyroku z dnia 18 maja 1994 r. (sygn akt 1438/93): „[...] kiedy przepisy podatkowe zawierają własna, normatywna definicję gospodarstwa rolnego, nie ma podstaw do rozważania - dla celów podatkowych - czy konkretna nieruchomość może być uznana za gospodarstwo rolne w rozumieniu przepisów art. $55^{3}$ kodeksu cywilnego. W żadnym bowiem razie wnioski wyprowadzone z takich rozważań nie mogłyby wpłynąć na uchylenie stosowania konkretnego przepisu zamieszczonego w prawie podatkowym; byłoby to łamanie prawa, „Wspólnota” 1994, nr 32.

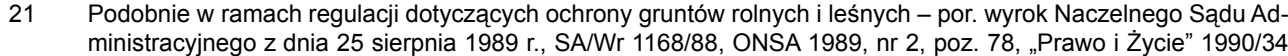
s. 15: W sprawach o wyłączenie gruntów rolnych z produkcji rolnej (ustawa z 26 marca 1982 r. o ochronie gruntów rolnych i leśnych - Dz.U. Nr 11 poz. 79), dane wynikajace z ewidencji gruntów sa wiążącym miernikiem oceny zarówno co do rolniczego charakteru określonych gruntów, jak i co do bonitacyjnej klasy gleby, ustalonej na podstawie przepisów rozporządzenia Rady Ministrów z 4 czerwca 1956 r. w sprawie klasyfikacji gruntów (Dz.U. Nr 19 poz. 97 z późn. zm.). 
nego rozumianego jak wyżej. Nieruchomość darowana lub otrzymywana w spadku nie musi być więc gospodarstwem rolnym, tylko z gospodarstwa rolnego musi wychodzić. Jeżeli na przykład darczyńca ma gospodarstwo rolne o powierzchni 5 ha użytków rolnych i darowuje swojemu sąsiadowi 0,5 ha użytków rolnych (nie przekraczając jednocześnie wielkości 1 ha przeliczeniowego), to nieruchomość ta będzie zwolniona od opodatkowania (oczywiście po spełnieniu dalszych warunków, o czym niżej), nawet wtedy, gdy obdarowany sąsiad nie ma żadnych nieruchomości.

W przypadku, gdy darczyńca posiada tylko 0,5 ha gruntów rolnych niestanowiących gospodarstwa rolnego, darowizna będzie zwolniona z opodatkowania wtedy, gdy sąsiad będzie właścicielem (posiadaczem) gruntów rolnych o powierzchni przekraczającej łącznie z gruntami otrzymanymi 1 ha (lub 1 ha przeliczeniowy). I tutaj pojawia się trzecia sytuacja przewidziana w przepisie, albo wejdzie w skład gospodarstwa rolnego będącego własnością nabywcy. Obdarowanym lub spadkobiercą będzie więc osoba, która już jest właścicielem gospodarstwa rolnego. Tutaj należy uznać, iż ustawodawca zastosował pewien skrót myślowy w określeniu ,gospodarstwo rolne będące własnością nabywcy". Przyjąć należy, iż to gospodarstwo rolne winno być własnością nabywcy w rozumieniu ustawy o podatku rolnym, a nie jest to własność w rozumieniu cywilnoprawnym. Obdarowany nie musi być właścicielem gruntów, wystarczy, iż prowadzi on gospodarstwo rolne w rozumieniu przepisów o podatku rolnym, czyli jest właścicielem lub posiadaczem (samoistnym lub zależnym) gruntów rolnych o powierzchni przekraczającej 1 ha lub 1 ha przeliczeniowy.

Jak natomiast rozumieć zwrot ,wejdzie w skład gospodarstwa rolnego będącego własnością nabywcy"? Czy obdarowany powinien być właścicielem gospodarstwa przed darowizną, czy wystarczy, gdy razem z gruntami, które otrzymał, powinien mieć powyżej 1 ha użytków rolnych (1 ha przeliczeniowego)? Dokonując językowej wykładni powyższego sformułowania, musimy uznać, iż gospodarstwo rolne musi istnieć wcześniej, by nieruchomość mogła wejść w jego skład. Jednak drugi pogląd jest z punktu widzenia celu zwolnienia właściwszy. Winno być tak a przyszła redakcja przepisu mogłaby to zmienić - iż wystarczy, gdy grunty, które obdarowany posiadał wcześniej, łącznie z gruntami otrzymanymi przekroczą powierzchnię 1 ha (1 ha przeliczeniowego), aby uznać, iż weszły one w skład (nowo powstałego) gospodarstwa rolnego.

Nie ma znaczenia liczba osób dziedziczących w przypadku spadkobrania. Jeżeli nieruchomość przekracza 1 ha, to nie ma znaczenia, jaki jest udział danej osoby w tym gospodarstwie, gdyż i tak będzie to udział zwolniony. W przypadku współwłasności darowizna jakiegokolwiek udziału w nieruchomości stanowiącej zgodnie $\mathrm{z}$ definicją $\mathrm{z}$ ustawy o podatku rolnym gospodarstwo rolne, będzie zwolniona 
z opodatkowania. Bez względu na to, czy będzie to $1 / 2$ gospodarstwa, które ma 100 ha, czy też 1/100 gospodarstwa 1,5-hektarowego. Co za tym idzie, nie ma znaczenia liczba osób dziedziczących. Jeżeli np. spadkodawca przeznaczyłby w testamencie gospodarstwo rolne, które ma 1,1 ha użytków rolnych, 10 osobom, wówczas wszystkie te osoby zwolnione byłyby od podatku od spadków i darowizn, pod warunkiem, że prowadziłyby gospodarstwo rolne przez okres 5 lat.

Kolejny warunek dotyczy czasu prowadzenia gospodarstwa: i to gospodarstwo rolne będzie prowadzone przez nabywcę przez okres co najmniej 5 lat od dnia nabycia. „Prowadzenie gospodarstwa rolnego” - to pojęcie może być w konkretnych sytuacjach trudne do jednoznacznego określenia. Oprócz sytuacji oczywistych, gdy właściciel gospodarstwa sam w nim pracuje, pojawia się szereg sytuacji, które już tak oczywiste nie są. Czy jeżeli ktoś wynajmie osobę do zarządzania gospodarstwem, ale nadal podejmuje wszystkie ważne decyzje związane z tym gospodarstwem, to znaczy, że to gospodarstwo prowadzi czy nie? Czy konieczny jest osobisty, codzienny wkład pracy w prowadzenie gospodarstwa, czy też wystarczy, że zostaną podjęte ogólne decyzje co do losów gospodarstwa, zaś na co dzień pracować w nim będą inne osoby (na przykład pracownicy najemni)? Uznać należy, iż wydzierżawienie gruntów powoduje sytuację, w której nie możemy mówić o prowadzeniu gospodarstwa rolnego, jednak w przypadku, w którym brak jest codziennej obecności w gospodarstwie danej osoby, ale zachowuje ona pełną kontrolę nad tym, co w nim się dzieje i pełne kompetencje co wszelkich decyzji związanych z gospodarstwem, uznać należy, że osoba ta prowadzi gospodarstwo. Ustawa nie używa tu na przykład sformułowania osobiste prowadzenie gospodarstwa - tak jak jest to np. w ustawie o kształtowaniu ustroju rolnego ${ }^{22}$. Kolejnym warunkiem jest prowadzenie tego gospodarstwa rolnego, a więc tożsamość gruntów, gdyż grunty właśnie stanowią wyłączny składnik gospodarstwa rolnego ${ }^{23}$. Sprzedaż gruntów, nawet stanowiących niewielką część gospodarstwa zgodnie ze stanowiskiem organów skarbowych, spowoduje, że nie będzie to już to gospodarstwo. Natomiast sprzedaż trzody chlewnej, wycięcie drzew będących częściami składowymi, zburzenie budynków nie będzie skutowało utratą zwolnienia. Ale takie konsekwencje będzie miała zmiana przeznaczenia gruntów - gdy przestaną być to grunty rolne, nie będzie można mówić o gospodarstwie rolnym.

Czy zawsze konsekwencją zmian własnościowych będzie utrata prawa do zwolnienia? Jeżeli np. grunt zostanie sprzedany, przestanie być w posiadaniu samoistnym obdarowanego (spadkobiercy), ale nadal będzie w posiadaniu zależnym (będzie dzierżawiony), nie będzie faktycznej zmiany gospodarstwa, gdyż ustawa o podat-

Por. art. 6 ust. 2 ustawy z dnia 11 kwietnia 2003 r. o kształtowaniu ustroju rolnego, Dz.U. Nr 64, poz. 592 z późn. zm. „Uważa się, że osoba fizyczna: 1) osobiście prowadzi gospodarstwo rolne, jeżeli: a) pracuje w tym gospodarstwie, b) podejmuje wszelkie decyzje dotyczące prowadzenia działalności rolniczej w tym gospodarstwie". 
ku rolnym nie odróżnia posiadania samoistnego od zależnego. Dana nieruchomość może być częścią kilku gospodarstw rolnych w rozumieniu ustawy o podatku rolnym. Jeżeli dana działka gruntu (użytki rolne) ma właściciela, ale jednocześnie użytkuje ją jak właściciel inna osoba - jest więc ta osoba posiadaczem samoistnym i w ramach wykonywania posiadania samoistnego oddaje tę nieruchomość w dzierżawę. Działka ma zatem właściciela, posiadacza samoistnego i posiadacza zależnego. Przyjmijmy, iż działka ta ma 0,75 ha powierzchni, zaś zarówno właściciel, jak i posiadacz samoistny i zależny są właścicielami użytków rolnych o powierzchni 0,5 ha każdy. W takiej sytuacji każdy z nich posiada gospodarstwo rolne o powierzchni 1,25 ha. Działkę gruntu o powierzchni 0,75 ha wliczamy więc do wszystkich trzech gospodarstw rolnych. Zmiany w zakresie posiadania nie wpływają więc na status gospodarstwa rolnego z punktu widzenia istotnej w naszych rozważaniach definicji. Jednak gdy zostanie utracone posiadanie zarówno samoistne, jak i zależne, wówczas należy uznać, iż tożsamość gospodarstwa zostanie naruszona, co skutkuje utratą prawa do zwolnienia. Zmiany - niekoniecznie w zakresie własnościowym - ściśle rzecz biorąc zmiany w zakresie posiadania, skutkować będą utratą prawa do zwolnienia. Uznać wobec tego należy, iż zmiany własnościowe są możliwe - pod warunkiem zachowania tożsamości podmiotu gospodarującego.

Niestety, wszelkie zmiany w zakresie wielkości gospodarstwa traktowane są przez organy skarbowe bardzo negatywnie dla podatnika. Jakiekolwiek zmiany w zakresie własnościowym uważane są za naruszenie warunków zwolnienia ${ }^{24}$. Oczywiste jest jednak, że pełne zachowanie tożsamości gospodarstwa prowadzić może do absurdalnych sytuacji ${ }^{25}$, gdy nawet niewielka, w pełni uzasadniona gospodarczo zmiana powierzchni gospodarstwa prowadzi do utraty zwolnienia. Można oczywiście znaleźć sytuacje, które naruszają tożsamość gruntów gospodarstwa, ale nie powinny mieć negatywnych skutków dla zwolnienia, na przykład zmiany powstałe na skutek procesu scaleniowego gruntów. W przypadku scalenia należy uznać, iż mimo braku pełnej tożsamości gruntów gospodarstwa charakter tego postępowania powoduje, iż mamy do czynienia z tym samym gospodarstwem rolnym

Por. np. wyjaśnienie Dyrektora Izby Skarbowej w Poznaniu z dnia 27.05.2011 r., sygn. ILPB2/436-43/11-4/MK (na stronie www.mf.gov.pl): Wnioskodawca, chcąc skorzystać ze zwolnienia, musi prowadzić gospodarstwo rolne obejmujące wszystkie działki nabyte ww. tytułem. Fakt, że po zbyciu działki nadal będzie prowadził gospodarstwo rolne, nie powoduje, że zostanie zachowane prawo do zwolnienia z art. 4 ust. 1 pkt 1 ustawy o podatku od spadków i darowizn.

Por. S. Babiarz, A. Mariański, W. Nykiel, Ustawa o podatku od spadków i darowizn. Komentarz. (opublikowane w programie komputerowym LEX). Komentarz do art. 4: Zagadnienie pogorszenia (umniejszenia) nabytego bądź tylko już posiadanego przez nabywcę gospodarstwa rolnego nie ma natomiast charakteru wątpliwości pozornej. Zwolennicy (przede wszystkim urzędnicy skarbowi) teorii nieumniejszania przez okres co najmniej 5 lat powierzchni gospodarstwa rolnego swój pogląd wywodzą z wykładni językowej sensu stricto (by nie rzec strictissime) przepisu art. 4 ust. 1 pkt 1 u.p.s.d., a w szczególności z użycia przez ustawodawcę zwrotu „i to gospodarstwo". Ma to bowiem oznaczać obowiązek zachowania tożsamości powierzchniowej tego gospodarstwa. Wydaje się jednak, że taka wykładnia byłaby sprzeczna z celem i istotą zwolnienia, bowiem zakazywałaby nawet dokonania zamiany gruntów gospodarstwa, i to również takiej, która prowadziłaby do poprawienia jego struktury. 
w rozumieniu przepisów ustawy o podatku rolnym, mimo wystąpienia niewielkich zmian w powierzchni gruntów.

Gdy darowiźnie podlega część gospodarstwa rolnego - tj. np. 0,5 ha - a obdarowany nie ma żadnych gruntów, nie mamy wówczas do czynienia z gospodarstwem rolnym. Obdarowany nie jest właścicielem gospodarstwa rolnego, nie może też prowadzić gospodarstwa rolnego. Uznać należy, iż nie mamy wtedy do czynienia z warunkiem dotyczącym konieczności prowadzenia gospodarstwa przez 5 lat.

\section{Wnioski}

Obecne regulacje w ustawie o podatku od spadków i darowizn dotyczące gospodarstw rolnych w stosunku do obowiązujących poprzednio ocenić należy pozytywnie. Przede wszystkim rozszerzono zakres zwolnienia na części składowe gospodarstw rolnych, co ma istotne znaczenie praktyczne ze względu na często znaczną, większą od gruntu, wartość budynków gospodarczych i innych trwale z gruntem związanych urządzeń. Jednak przepisom tym nadal daleko do precyzji. Niestety, na styku prawa cywilnego i prawa podatkowego często natrafiamy na problemy trudne do rozstrzygnięcia. Stosowanie definicji gospodarstwa rolnego z ustawy o podatku rolnym do rozstrzygnięcia sytuacji typowo cywilnoprawnych (darowizna, spadkobranie) powoduje niepotrzebne komplikacje i trudności interpretacyjne.

W pełni należy się zgodzić ze zdaniem, iż [...] z samej idei podatku spadkowego wynika, że rozwiązania prawnofinansowe mają w stosunku do cywilnoprawnych charakter wtórny ${ }^{26}$. I to właśnie rozwiązania cywilnoprawne - a więc przede definicja gospodarstwa rolnego z kodeksu cywilnego - winny być podstawą do określenia przedmiotu zwolnienia.

W pełni pozytywnie należy również ocenić obowiązujące obecnie zwolnienie z podatku od spadków i darowizn osób najbliższych. Dotyczy to oczywiście wszelkich sytuacji, nie tylko związanych z gospodarstwem rolnym, ale zdecydowanie ułatwia dokonywanie zmian pokoleniowych w rolnictwie. 


\section{Principles regulating exemption of farms from inheritance and donation taxation}

Key words: farm, donation, inheritance, transfer of the farm, taxation

The author presents currently binding regulations pertaining to exemption of inheritance and donation of a farm from inheritance and donation taxation. Since 2007 the nearest relatives have been exempted from this taxation, yet it is still imposed on further relatives and persons not related to the donor (decedent). Yet a gratuitous transfer of the farm is free from this taxation. The author focuses on the analysis of the conditions of this exemption, pointing to the lack of precision in its application. The use of taxation definition (of Agricultural Tax Statute) for specification of the conditions of exemption causes several interpretational problems. The definition of a farm, contained in the Civil Code, would be far more appropriate, as it is adjusted to the need of turnover and precisely points to the components vital for agricultural production. In author's opinion these components should be exempted from the inheritance and donation taxation. 